Weapons control

\section{Pugwash latest}

\section{Washington}

The thirty-first Pugwash meeting on arms control and nuclear disarmament took place last week at Banff in Alberta, but for the first time in its 24-year history, the Pugwash movement had visa applications rejected for two scientists who had been invited to attend the meeting.

The Canadian government refused permission for two Soviet scientists, Dr Vladimir Paylichenko of the presidium of the Soviet Academy of Sciences, and Dr Vladimir Ustinov, described as a specialist in disarmament and the history of science, to attend the meeting.

No reasons were given by the government for its decision, apart from the statement that it had been made on the grounds of national security.

On the first day of its meeting, the Pugwash council issued a strongly worded protest against the exclusion of the two Soviet scientists, claiming that "the suspicion and distrust which existed in 1957 which our meetings have always tried to dispel still exist, even in a country as open, friendly and generous as Canada".

The statement said that the Pugwash movement had always considered it essential that it should enable people to meet who hold different opinions, come from different backgrounds, and have different experiences. "We regard the exclusion of individuals whose presence we have invited as a breach of this principle against which we most strongly protest."

The council also said that the Canadian government's decision "makes it clear that Pugwash meetings are more urgently needed than ever before if nuclear war is to be averted and peace secured". Following agreement on this statement, a telegram protesting at the decisions was also sent to Canada's Ministry of External Affairs by all members of the Canadian delegation at the meeting.

No action, however, was taken by the nine Soviet scientists who were already attending the meeting, and who continued to participate in the closed sessions.

At the end of the week-long meeting, the council endorsed a so-called "suffocation" strategy for limiting the spread of nuclear weapons that had first been proposed three years ago by Canadian prime minister Pierre Trudeau. Under this strategy, an immediate moratorium on the deployment of new weapons would be followed by agreements to limit weapons production and tests, a ban on all nuclear tests and a cutoff in the production of fissile material.

The statement said that the Soviet and US governments should "reaffirm their intention to maintain equal security at more stable and lower force levels"'. It also considered it essential that serious negotations on limiting nuclear weapons in
Europe begin soon "before it is too late to set low limits", and in the context of moves that it said might destabilize the present balance of forces between East and West, suggested that highly accurate counterstrike missiles " are particularly dangerous since they create mutual fears of a first strike".

Soviet scientists at the meeting strongly denounced the United States for apparently dragging its feet over arms control negotiations. "The only obstacle on the way to arms control is the position of the United States," said Georgi A. Arbatov, director of the Soviet Institute for United States and Canadian Studies. The Soviet delegates resisted criticism of moves which had been taken by their own country.

One of the other proposals that the council agreed to support was for the United Nations to organize a global conference on international security. The council also advocated a "global approach" to the problem of future energy supplies and the potential conflicts that could arise over energy shortages.

"The general feeling is that it has been a very successful conference," said $\mathrm{Mr}$ William Epstein, the conference organizer and head of the Canadian delegation, adding that the refused visas had become " "a relatively minor issue after a small flurry on the first day."

David Dickson

\section{Forensic science}

\section{Evidence upheld}

Dr Colin Horncastle, the British forensic scientist who was taken off casework after publishing what has been described as a "farcical" and "archaic" paper on toxicology, last week lost his appeal against the ruling of an industrial tribunal. The tribunal had upheld the decision of Dr A. S. Curry, controller of the Forensic Science Service, to take Dr Horncastle off casework, ruling that the offer of a teaching post meant that he had not been effectively dismissed. The Employment Appeal Tribunal found last week that the original judgement had not erred on points of law.

Dr Horncastle's is one of three recent cases in which senior forensic scientists have been dismissed. Last week, the Home Office announced that $\mathrm{Dr}$ Alan Clift, a principal scientific officer with the West Midlands forensic service, is to be compulsorily retired "on grounds of limited efficiency". Dr Clift has given forensic evidence on at least one occasion which has led to a wrongful conviction. The third case concerns a police surgeon who was dismissed for giving evidence for the defence.

The Home Secretary has announced that all Dr Clift's cases since 1966 in which the defendant had pleaded not guilty but was convicted are to be reexamined. And there have been calls for a full inquiry into the running of the Forensic Science Service.
Forensic scientists themselves seem to be divided in their opinions.

The case of Dr Horncastle, who worked in Chepstow at one of seven regional forensic laboratories, began after a paper he had submitted in 1973 to the journal of the British Academy of Forensic Science, Medicine, Science and the Law, was published in 1977. Dr Alan Curry, with the advice of six toxicologists, considered that the paper cast doubt on Dr Horncastle's competence to give evidence in court and that it was the product of a deranged mind. Called "Toxicology: quantitative aspects", (Vol. 17, No. 1, p.37), the paper relates the drug content of organs to dose and estimates time of death using a simple law of linear diffusion. The data are scattered, leading the author to dwell on the uncertainties of forensic science.

Dr Horncastle was first moved from casework to research. But two years later, after a poor assessment of performance, a retirement board recommended that he be offered a teaching post, which he turned down last year in favour of voluntary retirement.

Dr Horncastle has argued that the paper he published in 1977 was very similar to a talk he delivered at the Forensic Science Service's Central Research Establishment at Aldermaston in 1969, which aroused no adverse comment even though Dr Curry was chairing the meeting. $\mathrm{He}$ also points out that in the years between writing and publication of the paper there had been no complaints about his work, and that he might never have been aware of the strength of opinion had he not taken his case to the Industrial Tribunal.

\section{Judy Redfearn}

\section{Air pollution control \\ Indoor hazards}

\section{Washington}

The US research community seems to be on a collision course with the Reagan Administration over the need for further study of the health effects of indoor air pollution, ranging from radon emitted by building materials to the second-hand effects of cigarette smoke, and the formaldehyde used in foam insulation.

Mrs Anne Gorsuch, the new administrator of the Environmental Protection Agency (EPA), has apparently decided on major reductions in the agency's support for research into indoor a i r

pollutants in the 1982 fiscal year, which begins next month, and to eliminate the research programme the following year.

These decisions follow close on the heels of a report published by the National Academy of Sciences which claims that although indoor exposure can constitute an important fraction of the total exposure to many pollutants, it has been largely overlooked in research on the health effects of environmental pollutants. In some cases, 